\title{
ARTERIOVENOUS FISTULA WITH A SAPHENOUS LONG LOOP
}

\author{
LUIS F. SILVEIRA, M.D., and JOAO A. PATRICIO, M.D.
}

After radiation, chronic infection or previous operations recipient vessels for free tissue transfer become difficult to find. It may be necessary to locate vessels remote from the area of reconstruction and to construct long venous grafts. Long venous grafts can be compressed in the tissue tunnels that may be required. In this series of patients, an arteriovenous fistula was created with a long saphenous loop 10 to 21 days prior to tissue transfer. The saphenous loops were placed close to the area for reconstruction and when divided at the time of transplantation, provided one artery and one vein. In this series of 12 cases, adequate vascularization was achieved in 10 cases. In the other 2 cases, we believe that maturation of the fistula may have been necessary before proper function. The other advantages of the technique are: the procedure can be carried out under local anaesthesia, ease of positioning of the patient on the operating table, and a reduction in the time taken to perform the tissue transfer.

(c) 1993 Wiley-Liss, Inc.
When free grafts are used for reconstructive surgery, it is sometimes difficult to find adequate recipient vessels. There are several reasons for poor recipient vessels: small calibre, difficult access, atherosclerosis, radiation damage, chronic infection, and extensive surgical dissection. ${ }^{1}$ In this situation, it is necessary to look for vessels that are remote from the lesion and to create long venous grafts (LVG) for reestablishment of blood flow to the free flap vessels. This method creates a new blood supply and reconstructs the damaged tissues at the same operation. This is not without its complications or failures. As there may be a long route for the venous grafts, the flap blood supply may be compromised by haematoma or oedema. There is an approximately $10 \%$ failure rate in free transplantations. ${ }^{2-4} \mathrm{An}$ alternative method is to create an arteriovenous fistula with a saphenous vein long loop (AVFSLL). ${ }^{5}$ Once the long loop is sectioned at the time of tissue transfer, there is one artery and one vein. ${ }^{3,6}$

\section{PATIENTS AND METHODS}

The AVFSLL was performed in 12 patients (ten men and two women) with an age range of 28 to 77 years (mean 53.6 years). All the patients underwent surgery at the Departments of Surgery I and II of the Hospitais da Universidade de Coimbra. Table 1 shows the age, sex, pathology, and flaps of each patient. Six patients presented with infections of the lower limb, five had tumours of the head, ${ }^{7}$ and one had a scrotal avulsion and partial loss of the penis secondary to perineal trauma. ${ }^{8}$

None of the patients had good recipient vessels in the

From the Department of Surgery (L.F.S.) and Department of Surgery II (J.A.P.), Hospitais da Universidade de Coimbra, 3000 Coimbra, Portugal.

Received for publication December 25, 1992.

(c) 1993 Wiley-Liss, Inc area of the reconstruction. The omentum was the tissue of choice because of its resistance to infection ( 3 cases), its resistance to tumorous invasion ( 5 cases; one with a gastroepiploic free flap) and its capacity to cover extensive and irregular surfaces ( 3 cases). A latissimus dorsi free flap was used in one case on an infected open tibial fracture and a free intestinal loop was used for urethral reconstruction.

Two patients underwent the creation of the fistula under local anaesthesia; the others received a general anaesthetic. The fistula was created by one of two methods: in some patients the vein was divided distally and anastomosed to the recipient artery, the proximal part of the vein being left in continuity; in others a vein graft was transposed and anastomosed to the recipient artery (end-to-side) and to one vein with good drainage. In both methods the result is a " $U$ " shaped loop with the superficialised loop placed close to the area of reconstruction. The delay between loop creation and tissue transfer was 10 to 21 days. The AVFSLL was only used if it was functional with a good flow. The length of the graft was 26 to $45 \mathrm{~cm}$ (mean $38 \mathrm{~cm}$ ). After creation of the free flap and transfer to the recipient bed, the saphenous loop was sectioned in its middle part. The arterial limb was anastomosed to the flap artery and the venous limb to the flap vein or veins (end-to-end or end-to-side).

\section{RESULTS}

In two cases, there was thrombosis of the AVFSLL. The reason for the thrombosis may have been the lack of patient care of the limb (case 6) and compression of the loop by local oedema (case 5). In the other 10 patients, the fistula was functional and effective. In each case it was possible to place the loop superficially close to the recipient bed. Thus, it was possible to get good calibre vessels which permitted good microsurgical anatomoses and assured the free flap blood supply. There were no serious postoperative compli- 
Table 1. Details of Patients.

\begin{tabular}{|c|c|c|c|c|}
\hline Patient & Sex & Age & Pathology & Free graft \\
\hline 1 & $\mathbf{M}$ & 28 & Scrotal laceration & Intestinal loop \\
\hline 2 & $M$ & 48 & Osteomyelitis tibia & Omentum \\
\hline 3 & M & 54 & Osteomyelitis tibia & Omentum \\
\hline 4 & $M$ & 36 & Osteomyelitis tibia & Latissimus dorsi \\
\hline 5 & M & 57 & Ulcerated lymphoedema & Vein graft failure \\
\hline 6 & M & 53 & Osteomyelitis calcaneum & Vein graft failure \\
\hline 7 & M & 64 & Gluteus radiodermatitis & Omentum \\
\hline 8 & $F$ & 77 & $\begin{array}{l}\text { Basal cell carcinoma of the } \\
\text { face }\end{array}$ & Omentum \\
\hline 9 & M & 52 & Meningioma & Omentum \\
\hline 10 & M & 56 & $\begin{array}{l}\text { Basal cell carcinoma of the } \\
\text { head }\end{array}$ & Omentum \\
\hline 11 & M & 65 & Epithelioma of the head & Omentum \\
\hline 12 & $\mathrm{~F}$ & 74 & $\begin{array}{l}\text { Basal cell carcimoma of the } \\
\text { head }\end{array}$ & Gastroepiploic \\
\hline
\end{tabular}

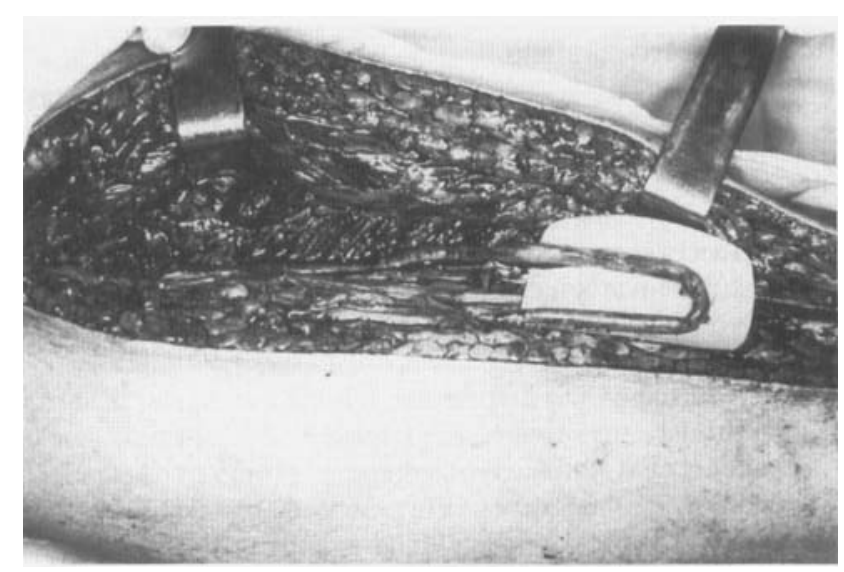

Figure 1. Saphenous long-loop arteriovenus fistula.

cations, but partial necrosis of the omental free graft occurred in 2 cases. This was due to an incorrect placement of the patient in bed but id did not compromise the final result.

The follow-up shows three tumour recurrences at 13, 9, and 4 months in cases 8,10 , and 11 , respectively but there was no invasion of the omentum and the AVFSLL remained functional. The AVFSLL remains functional in all other cases with a follow-up of one to four years.

\section{DISCUSSION}

Either long venous grafts or AVFSLLs can be used when a free tissue transfer is required but there are poor recipient vessels. Both methods result in good calibre vessels which can be placed in a superficial site ready to receive the flap.

The disadvantages of using an LVG are the increased operating time and the need to reposition the patient during the procedure. The long venous graft may also be in danger because of the need to route the graft through a tunnel and expose the graft to possible compression due to oedema or haematoma. Further, it is necessary to perform several anastomoses at the same time: two proximal (recipient artery and vein to graft) and two or three distal anastomoses (venous graft to tissue transfer vessels); this may increase the risk of thrombosis in the vessels.

We believe that if the AVFSLL construction is made prior to the reconstructive surgery, it presents several advantages such as the use of local anaesthesia to create the fistula, shortening of the surgical time for the flap transfer and eliminating the need to reposition the patient during the procedure. Besides these factors, the time between the fistula formation and the free tissue transfer permits maturation of the fistula- the vascular anastomoses stabilize themselves and the venous graft adapts itself well to the arterial flow and to the surrounding tissues. The loop is then sectioned and transformed into the recipient artery and vein. In this way only two or three anastomoses are performed at any time. In our two failures, if we had opted for an LVG we would have lost the tissue transfer as well as the venous graft.

\section{CONCLUSIONS}

The construction of an arteriovenous fistula from a saphenous long loop revealed itself as being useful for creation of good recipient vessels. In 10 of 12 cases presented here, the vascular viability of the subsequent free tissue transfer was assured.

\section{REFERENCES}

1. Masquelet AC, Valenti Ph, Destable MD: Lambeaux libres avec pontages aux membre inferieurs. Abstract, XVlème Renconstre Internationale de Microchirurgie du GAM, Coimbra, 27th-29th May 1990, p 79.

2. Germain M-A, Patricio J, Launois B, Hureau J: Les transplants libres avec double pontage vasculaire en microchirurgie. Chirurgie 117:245246, 1991.

3. Gluckman J-L, McCafferty G-L: Complication associated with free jejunal graft reconstruction of the pharyngo-oesophagus. A multi-institutional experience with 52 cases. Head and Neck Surgery 7:200-205, 1985.

4. Silveira L, Falcao F, Barros F, Patricio J: Epiplooplastie en cancerologie de la téte-a propos d'un cas-traitement primaire et de la recurrence. Abstract, XVIème Renconstre Internationale de Microchirurgie du GAM, Coimbra, 27th-29th May 1990, p 105.

5. Germain M-A, Chasseray V, Launois B, Hureau $J$ : Autotransplantation d'intestin gréle, operation de sauvetage en urgence après échecs d'oesophagoplaties. Journal de Chirurgie 127:572-574, 1990.

6. Germain M-A: L'essor des transplants libres antebrachiaux. Instantanés Médicaux 3:39-42, 1988.

7. Silveira L, Falcao F. Barros F, Patricio J: Pointages veineuses longues pour des transplants libres-deux methodes alternatives. Abstract, XVIème Renconstre Internationale de Microchirurgie du GAM, Coimbra, 27th-29th May 1990, p 77.

8. Patricio J, Silveira L, Falcao F, Velez A, Cabrita S: Free intestinal graft for urethral reconstruction. Abstract, XVIème Renconstre Internationale de Microchirurgie du GAM, Coimbra, 27th-29th May 1990, p 39. 